\title{
The Implementation Production Unit Expertise Dressmaking Program in Vocational High School (SMK) Malang
}

\author{
Annisau Nafiah $^{1 *}$ Soenar Soekopitojo ${ }^{2}$ Hakkun Elmunsyah ${ }^{3}$ \\ ${ }^{1}, 2,3$ Department of Industrial Technology Universitas Negeri Malang \\ "Corresponding author Email: annisau.nafiah.ft@um.ac.id
}

\begin{abstract}
:
This study describes the operation of the production units Dressmaking Skills Program at vocational high school in Malang. This research is quantitative descriptive. The results showed that the production unit of the Fashion Design Expertise Program vocational high schools in Malang running very good. This is evidenced from the acquisition of an average $57.58 \%$ categorized very good. Although it has been classified as very good, it still needs to be improved further in order to optimize the existence of the school production unit, special handling is needed so that the existing production units can be further developed, the need for special personnel or employees who are given special tasks to manage the school production units. The workload of the teacher who is the administrator of the production unit is also an important point that needs attention. But in reality, this matter has not been given special attention and teachers who are given the task to become administrators still have the same teaching assignments or burdens as other teachers.
\end{abstract}

Keywords: evaluation, production unit, vocational

\section{INTRODUCTION}

Vocational education is education that connects, matches, and trains people to have the habit of working to be able to enter and develop in the world of work (industry) so that it can be used to improve their lives. At the level of vocational education, students are expected to have the skills, knowledge, and attitudes so that graduates are ready to use and competent in entering the workforce. Sutopo (2012) in his research stated that: (1) most UPs were active, but the contribution of some learning facilities and operational funding sources was still relatively small, (2) most UP programs were able to harmonize curriculum programs, but the utilization of Sarpras and HR was not optimal, (3) improvement of students' knowledge and skills is achieved, but the number is limited, (4) effectiveness as a learning tool is achieved, but the number of students and teachers involved is relatively small, (5) construction quality and materials are high and the selling price is standard, but the display quality is not yet maximum, (6) increase the welfare of school residents, and school income, and (7) most UPs are trusted by the community / industry. Based on observations made by the author in several schools in Malang on the Fashion Design expertise program, the existence of UP has not fully run optimally. Many obstacles are faced and need special handling so that the UP can run and develop as expected. Constraints that are often encountered are (1) management system that is less than the maximum due to lack of focus in controlling the UP itself, (2) most UPs are held by teachers who teach, while their tasks are mostly related to the KBM process, (3) lack of focus in the management of UP in schools, and (4) student involvement is also not fully utilized.

Related to the importance of organizing the Production Unit which is carried out at the Vocational School, especially in the Fashion Design expertise program, it is necessary to have research in order to determine the level of success of the implementation of the production unit. The research objective is to obtain accurate and objective information about a program. The information can be in the form of the program implementation process, the impact / results achieved, efficiency and utilization of the evaluation results that are focused on the program, namely to make a decision whether to proceed, repair, or stop. In addition, it is also used for the purposes of the preparation of the next program and formulation of policies related to the program.

\section{METHOD}

The design of this study is quantitative descriptive using surveys, observations, and interviews in data collection. The results of quantitative data will be processed using SPSS (Statistical Product and Service Solution) ver 20.0 for windows. The purpose of this study is to describe the process of organizing the production unit of the Fashion 
Design Expertise Program in Vocational Schools in Malang. The survey was carried out directly on the schools studied involving all productive dressmaking teachers and administrators involved in the school production unit and all students. Observation and interviews are needed to support the completeness of the data obtained by looking directly at the conditions in the field and getting information directly from the resource person who is in charge of the school production unit.

The population of this research is all SMKs in Malang in the Fashion Design Expertise Program which have school production units that are still running until now. There are three SMKs throughout Malang that have a Fashion Design expertise program, namely SMKN 3 Malang, SMKN 5 Malang, and SMKN 7 Malang. This study involved all productive teachers in Clothing, all administrators, and all students involved in the school production unit. The population of productive teachers in dressmaking and administrators of the school production units involved in this study amounted to 36 people. While students involved in the implementation of the production unit numbered 120 people.

\section{RESULTS AND DISCUSSION}

Based on a descriptive analysis of the process of organizing the production unit of the Fashion Design Expertise Program in SMKN 3 Malang, SMKN 5 Malang, SMKN 7 Malang, and SMK in Malang by the teacher, the average value of SMKN 3 Malang 55.74, SMKN 5 Malang average value average 58.10, SMK 7 Malang average value 58.75, SMK in Malang average value 56.82. A summary of the results of the descriptive analysis as presented in Table 4.5 follows.

Table 4.5 Summary of Results of Descriptive Analysis of Production Unit Operational Scores Fashion Skills Program Seen from the Terms of Process at SMKN 3 Malang, SMK 5 Malang, SMK 7 Malang, and SMK Malang by Teachers

\begin{tabular}{ccccc}
\hline School & Min value & Max value & Mean & Standar Deviasi \\
\hline SMKN 3 Malang & 50 & 65 & 55,74 & 4,593 \\
\hline SMKN 5 Malang & 51 & 64 & 58,10 & 4,725 \\
\hline SMKN 7 Malang & 57 & 63 & 58,75 & 2,872 \\
\hline SMK se-Kota Malang & 50 & 65 & 56,82 & 4,538 \\
\hline
\end{tabular}

In summary, the percentage score classification of the results of the research of the production unit of the Fashion Design Expertise program in terms of processes in SMKN
3 Malang, SMKN 5 Malang, SMKN 7 Malang, and SMK in Malang by teachers is presented in Table 4.6.

Table 4.6 Summary of Results of Descriptive Analysis of Production Unit Operational Scores Fashion Skills Program Seen from the Terms of Process at SMKN 3 Malang, SMK 5 Malang, SMK 7 Malang, and SMK Malang by Teachers

\begin{tabular}{|c|c|c|c|c|c|c|}
\hline \multirow[b]{2}{*}{ No } & \multirow[b]{2}{*}{ categories } & \multirow[b]{2}{*}{$\begin{array}{c}\text { Range interval } \\
\text { class }\end{array}$} & \multicolumn{4}{|c|}{ percentage $(\%)$} \\
\hline & & & $\begin{array}{c}\text { SMKN } \\
\mathbf{3} \\
\text { Malang }\end{array}$ & $\begin{array}{c}\text { SMKN } \\
5 \\
\text { Malang }\end{array}$ & $\begin{array}{l}\text { SMKN } 7 \\
\text { Malang }\end{array}$ & $\begin{array}{c}\text { SMK Se- } \\
\text { Kota } \\
\text { Malang }\end{array}$ \\
\hline 1. & Very very good & $63-72$ & 10,53 & 30 & 25 & 18,18 \\
\hline 2. & Very good & $54-62$ & 47,37 & 50 & 50 & 51,52 \\
\hline 3. & Good & $45-53$ & 42,10 & 20 & 25 & 30,30 \\
\hline 4. & Enaught & $36-44$ & 0,00 & 0,00 & 0,00 & 0,00 \\
\hline 5. & Less & $27-35$ & 0,00 & 0,00 & 0,00 & 0,00 \\
\hline 6. & Very less & $18-26$ & 0,00 & 0,00 & 0,00 & 0,00 \\
\hline & Total & & 100 & 100 & 100 & 100 \\
\hline
\end{tabular}

Based on table 4.6 shows that the results of research on the implementation of the Production Unit of Clothing Skills Program in terms of processes in SMKN 3 Malang, SMKN 5 Malang, SMKN 7 Malang, and SMK in Malang by teachers can be categorized very good. This is concluded from the percentage of each school that is SMKN 3 Malang, there are $47.37 \%$ of respondents think very good; $10.53 \%$ thought very good; and $42.10 \%$ were of good opinion; SMKN 5 Malang, there are $50 \%$ of respondents think very good; $30 \%$ thought very good; and $20 \%$ think good; SMK 7 Malang, there are $50 \%$ of respondents think very good; $25 \%$ thought very good and
$25 \%$ thought good; Vocational Schools in Malang, there are $51.52 \%$ of respondents think very good; $18.18 \%$ think very good and $30.30 \%$ think good. Most of the scores are in the range between 54-62 with the percentage of each SMKN 3 Malang 47.37\%, SMKN 5 Malang 50\%, SMKN 7 Malang 50\%, and SMKs in Malang City 51.52\% which are categorized very good, so that it can be interpreted that the implementation of the production unit of the Fashion Design Expertise program in terms of processes by the teacher is already going very good.

Based on a descriptive analysis of the implementation of the production unit of the Fashion Craftsmanship Program 
in terms of processes in SMKN 3 Malang, SMKN 5 Malang, SMKN 7 Malang, and SMK in Malang by students, it can be obtained the average value of SMKN 3 Malang 14.33, SMKN 5 Malang scores an average of 12.88, SMKN 7 Malang averages 14.17 , while SMKs in Malang average an average of 13.62. The complete results of the descriptive analysis of the implementation of the production unit of the Fashion Craftsmanship Program in terms of processes in SMKN 3 Malang, SMKN 5 Malang, SMKN 7 Malang, and SMK in Malang by students are presented in Appendix 7 page 134. Summary of descriptive analysis results as presented in the following Table 4.7.

Table 4.7 Summary of Results of Descriptive Analysis of Production Unit Operational Scores Fashion Skills Program Seen from the Terms of Process at SMKN 3 Malang, SMKN 5 Malang, SMKN 7 Malang, and SMKs throughout Malang by Students

\begin{tabular}{ccccc}
\hline School & Min value & Max value & Mean & Standar Deviasi \\
\hline SMKN 3 Malang & 11 & 16 & 14,33 & 1,331 \\
\hline SMKN 5 Malang & 11 & 15 & 12,88 & 1,255 \\
\hline SMKN 7 Malang & 12 & 16 & 14,17 & 1,043 \\
\hline SMK se-Kota Malang & 11 & 16 & 13,62 & 1,433 \\
\hline
\end{tabular}

Item of the questionnaire statement of organizing the production unit of the Fashion Craftsmanship Program in terms of processes in SMKN 3 Malang, SMKN 5 Malang, SMKN 7 Malang, and SMK in Malang by 5 students, it can be calculated that the ideal minimum score that might be achieved is 5 and an ideal maximum of 20 . In summary, the percentage of the score of the organizing of the production unit of the Fashion Craftsmanship Program in terms of processes in SMKN 3 Malang, SMKN 5 Malang, SMKN 7 Malang, and SMK in Malang by students, is presented in Table 4.8 .

Table 4.8 Percentage of Operation of the Fashion Design Expertise Production Unit Judging from the terms of the Process in SMKN 3 Malang, SMKN 5 Malang, SMKN 7 Malang, and SMKs throughout Malang by students

\begin{tabular}{|c|c|c|c|c|c|c|}
\hline \multirow[b]{2}{*}{ No } & \multirow[b]{2}{*}{ Categories } & \multirow[b]{2}{*}{$\begin{array}{c}\text { Range } \\
\text { interval } \\
\text { class }\end{array}$} & \multicolumn{3}{|c|}{ percentage $(\%)$} & \multirow{2}{*}{$\begin{array}{c}\text { No } \\
\text { SMK Se- } \\
\text { Kota } \\
\text { Malang }\end{array}$} \\
\hline & & & $\begin{array}{c}\text { SMKN } \\
3 \\
\text { Malang }\end{array}$ & $\begin{array}{c}\text { SMKN } \\
5 \\
\text { Malang }\end{array}$ & $\begin{array}{c}\text { SMKN } \\
7 \\
\text { Malang }\end{array}$ & \\
\hline 1. & Very very good & $14-16$ & 71,11 & 31,58 & 88,89 & 53,33 \\
\hline 2. & Very good & $12-13$ & 26,67 & 57,90 & 11,11 & 40 \\
\hline 3. & Good & $10-11$ & 2,22 & 10,52 & 0,00 & 6,67 \\
\hline 4. & Enaught & $8-9$ & 0,00 & 0,00 & 0,00 & 0,00 \\
\hline 5. & Less & $6-7$ & 0,00 & 0,00 & 0,00 & 0,00 \\
\hline 6. & Very less & $4-5$ & 0,00 & 0,00 & 0,00 & 0,00 \\
\hline & Total & & 100 & 100 & 100 & \\
\hline
\end{tabular}

Based on Table 4.12 shows that the results of the implementation of the production unit of the Fashion Craftsmanship Program in terms of processes in SMKN 3 Malang, SMKN 5 Malang, SMKN 7 Malang, and SMK in Malang by students can be categorized very good. This is concluded from the percentage of each school, namely SMKN 3 Malang, there are $26.67 \%$ of respondents think very good; $71.11 \%$ thought very good; and $2.22 \%$ were of good opinion; SMKN 5 Malang, there are $57.90 \%$ of respondents think very good; $31.58 \%$ thought very good; and $10.52 \%$ thought it was good; SMK 7 Malang there are $11,11 \%$ of respondents think very good; and $88.89 \%$ were of good opinion; Malang City Vocational School there were $53.33 \%$ of respondents thought very good, $40 \%$ thought very good, and $6.67 \%$ thought good. Most of the scores were in the range between 14-16 with the percentage of each SMKN 3 Malang $71.11 \%$, SMKN 7 Malang 58.89\%, and Malang City Vocational High School $53.33 \%$ which were categorized very good, while SMKN
5 Malang most scores in the range 12-13 with the percentage of $57.90 \%$ which is categorized very good

\section{CONCLUSION}

The implementation of the production unit of Fashion Design Expertise Program in Vocational Schools in Malang viewed from the aspect of the process by the teacher includes: the management of the production unit, the ability of the instructor, the operation of the production unit, the parties responsible for the operation of the production unit, the obstacles encountered in the unit production, and the benefits of operating a production unit. In general, the implementation of the production unit of the Fashion Design Expertise Program in Vocational Schools in Malang in terms of processes by the teacher has been going very good. This is evidenced from the average value of 56.82 or $51.52 \%$ categorized very good. While the involvement of students in the operation of the 
technical education: planinning, content, and

production unit has also gone very good, as evidenced by the average value obtained 13.62 or $53.33 \%$ which is categorized very good. The results of research conducted at SMKN 3 Malang obtained an average value of 55.74 or $47.37 \%$ categorized very good. While the involvement of students in the implementation of the Production Unit has also been going very good, as evidenced by the average value obtained 14.33 or $71.11 \%$ which is categorized very good. In contrast to the implementation of the production unit at SMKN 5 Malang by students, the average value is 12.88 or $57.90 \%$ which is categorized very good, while the involvement of teachers is categorized very good as indicated by the average results of 58.10 or $50 \%$.

The implementation of the production unit in terms of processes in SMKN 7 Malang by teachers has been going very good with an average value of 58.75 or $51.52 \%$. While the involvement of students is categorized very good as shown by the average results obtained 14.17 or $88.89 \%$. Even though it has been categorized very good, it still needs to be improved again so that the production unit is really very good organized. Teacher and student competency improvement needs to be developed by following skills competency training because the production unit is used as a vehicle for learning and fostering entrepreneurial spirits.

Based on the guidelines for the implementation of the production unit Dikmejur (2007) the objectives of organizing these activities are: (1) as a production / service-based training facility for students, (2) a vehicle for fostering and developing the entrepreneurial spirit of teachers and students in vocational schools, (3) a means of productive productive practice directly for students, (4) help funding for maintenance, additional facilities and other educational operational costs, (5) increase the spirit of togetherness, because it can be a vehicle for increasing productive activities of teachers and students as good as providing 'income' and increasing the welfare of school residents, (6) develop an independent attitude and confidence in the implementation of student practice activities. The organization of production units in schools is intended to gain professional expertise for students which can only be obtained through doing direct work in accordance with market needs.

\section{REFERENCES}

[1] Arikunto, S. 2007. Dasar-Dasar Evaluasi Pendidikan. Jakarta: Bumi Aksara.

[2] Arikunto, S. 2006. Prosedur Penelitian Suatu Pendekatan Praktik. Jakarta: PT. Rineka Cipta.

[3] Arikunto, S., dkk. 2008. Evaluasi Program Pendidikan Pedoman Teoretis Praktis Bagi Praktisi Pendidikan. Jakarta: Bumi Aksara.

[4] Atmodiwirio, S. 2002. Manajemen Pelatihan. Jakarta: PT. Ardadizya Jaya.

[5] Crunkilton, R. J \& Finch, R.C. 1999. Curriculum development in vocational and implementation. MA. Boston: Needham heights.

[6] Depdikbud. 1990 a. Program Pengembangan Pendidikan Menengah Kejuruan Dalam Pelita v. Jakarta: Dirjen Dikdasmen Dikmenjur.

[7] Depdikbud. 1993.Kepmendikbud No. 080/U/1993 Tentang Kurikulum SMK. Jakarta: Depdikbud.

[8] Depdikbud. 1993. Informasi Pendidikan Menengah Kejuruan. Jakarta: Depdikbud.

[9] Depdiknas. 2006. Penyelenggaraan Sekolah Menengah Kejuruan Bertaraf Nasional. Jakarta: Direktorat Pembinaan Sekolah menengah Kejuruan Ditjen Dikdasmen.

[10] Depdiknas. 2007. Pedoman Manajemen Unit Produksi/Jasa Sebagai Sumber Belajar Siswa dan Penggalian Dana Pendidikan Persekolahan: Jakarta.

[11] Ernawati. 2006. Unit Produksi di SMK dan Masalah Pegembangannya. Jurnal Forum Pendidikan, 31 (3): 235-252.

[12] Firdaus, Z. Z. 2012. Pengaruh Praktik Kegiatan Unit Produksi Sekolah, Pengalaman $\begin{array}{llll}\text { Prakerin. } & 2 & \text { (3). }\end{array}$ (http://journal.uny.ac.id/index.php/jpv/article/v iew/1045), diakses 17 Februari 2014.

[13] Guruvalah. 2002. Kepala Sekolah Sebagai Wirausahawan (Online), (http://www.geocities.ws/guruvalah/entreprene ur kepsek.html), diakses 16 Desember 2013.

[14] Handoko, T. H. 2003. Manajemen Edisi 2. Yogyakarta: BPFE Yogyakarta.

[15] Hidajat, T. W. 2011. Persepsi Pengelola trhadap Peran Sistem Informasi Manajemen (SIM) Berbasis IT pada Pengelolaan Administrasi Sekolah Menengah Kejuruan (SMK) Di Kota Mojokerto. Tesis tidak diterbitkan. Malang: PPs UM.

[16] Ibnu, S dkk. 2003. Dasar-Dasar metodologi Penelitian.Universitas Negeri Malang dan Lembaga Penelitian Universitas Negeri Malang: Malang.

[17] Judowati, S. A, 2010. Keefektifan Pelaksanaan Program Unit Produksi Sekolah Menengah Kejuruan (SMK) Di Kota Blitar. Tesis tidak diterbitkan. Malang: PPs UM.

[18] Kotler, P. 2005. Manajemen Pemasaran Jilid 1. Jakarta: PT. Indeks Kelompok Gramedia.

[19] Kuswana, W. S. 2013. Dasar-dasar Pendidikan Vokasi \& Kejuruan. Bandung: Alfabeta.

[20] Lestari, Sri. 2010. Model Pengelolaan Unit Produksi di sekolah Menengah Kejuruan (http://digilib.uns.ac.id), diakses 17 Agustus 2015. 
[33] Sugiyono. 2008. Metode Penelitian Pendidikan Pendidikan Kuantitatif, Kualitatif, dan $R \& D$. Bandung: Alfabeta.

Evaluasi Pengajaran. Departemen Pendidikan dan Kebudayaan Institut Keguruan dan Ilmu Pendidikan Malang Proyek Operasi dan Perawatan Fasilitas. Malang.

[22] Martubi. 1998. Model-Model Penyelenggaraan Unit Produksi Di sekolah Menengah Kejuruan Daerah Istimewa Yogyakarta. Direktorat Pembinaan Penelitian dan penabdian Masyarakat Direktorat Jenderal Pendidikan Tinggi Departemen Pendidikan dan Kebudayaan: Yogyakarta.

[23] Mujaddi, C. U. 2014. Intensitas Pembelajaran Praktik Di Unit Produksi/Jasa, Sarana dan Prasarana Unit Produksi/jasa, dan Motivasi belajar Siswa Hubungannya Dengan Kompetensi Kerja Siswa SMK Negeri Di Kota Surabaya. Tesis tidak diterbitkan. Malang: PPs UM.

[24] Mulyatiningsih, E. 2011. Evaluasi Proses Suatu Program. Bumi Aksara: Jakarta.

[25] Nawawi, H. 2006. Ealuasi dan Manajemen Kinerja Dilingkungan Perusahaan dan Industri. Yogyakarta: Gadjah Mada Uniersity Press.

[26] Nurkancana, W. \& Sunartana. 1986. Evaluasi Pendidikan. Surabaya: Usaha Nasional.

[27] Pemeritah Republik Indonesia. 2003. UndangUndang Republik Indonesia Nomor 20 Tahun 2003 Tentang Sistem Pendidikan Nasional. Jakarta.

[28] Priyatno, D. 2008. Mandiri Belajar SPSS. Yogyakarta: MediaKom.

[29] Rusnani, 2012. Pelaksanaan Unit Produksi Pada Sekolah Menengah Kejuruan Negeri Kelompok Bisnis dan Manajemen. Jurnal Pendidikan Vokasi. 2 (3): 20-36.

[30] Rokhmawati, R. I. 2014. Integrasi TIK Dalam Pembelajaran Pada Program Studi Keahlian Teknik Komputer dan Informatika Di SMK Kota Malang. Tesis tidak diterbitkan. Malang: PPs UM.

[31] Siswanto, Ibnu. 2015. Faktor Pendukung dan Penghambat Pelaksanaan Unit Produksi Di SMK Daerah Yogyakarta. Jurnal PPKM II (Online),

(abcd.unsiq.ac.id/source/LP3MPB/Jurnal/2015

/Mei/2.\%20PPKM.V2.2-

Ibnu\%20Siswanto-

Faktor\%20Pendukung\%20dan\%Penghambat $\%$ 20Pelaksanaan\%20Unit\%20Produksi.pdf), diakses 17 Februari 2015.

[32] Saukah, A dkk. 2000. Pedoman Penulisan Karya Ilmiah. Universitas Negeri Malang: Malang.

[34] Sugiyono. 2006. Statistika Untuk Penelitian. Bandung: Alfabeta.

[36] Sunarto, Y. 2014. Kesiapan Pembelajaran Instrumentasi Sistem Otomasi I Dengan Menggunakan Model CIPP Dalam Rangka Pelaksanaan Uji Sertifikasi Kompetensi Teknikal Program Study teknik Mesin fakultas Teknik Universitas Negeri Malang. Tesis tidak diterbitkan. Malang: PPs UM.

[37] Suprapto, B. 2005. Pendidikan Sekolah Seutuhnya. Jakarta: Depdikbud.

[38] Sutopo, Adi. 2012. Evaluasi Efektifitas Unit Produksi Dalam Mempersiapkan Kompetensi Kerja Siswa SMK, 2 (3). (Online), (www.ejurnal.com/2014/02/ evaluasiefektivitas-unit-produksi.html), diakses 17 Februari 2014

[39] Rusnani. 2012. Pelaksanaan Unit Produksi Pada Sekolah Menengah Kejuruan Negeri, 2 (3) (Online), (http://journal.uny.ac.id/index.php/jpv/article/v iew/1041), diakses 17 Februari 2014.

[40] Tayibnapis, F.Y. 2000. Evaluasi Program. Jakarta: Rineka Cipta.

[41] Tim penyusun bahan ajar. 2006. Kurikulum Pendidikan Kejuruan. Universitas Negeri Malang: Malang.

[42] Viani, A. A. 1996. Efektivitas Program Bina Keluarga dan Balita (BKB). Tesis tidak diterbitkan. Jakarta: FPS-IKIP Jakarta.

[43] Winarsunu, T. 2006. Statistik dalam penelitian Psikologi dan Pendidikan. Malang: UMM Pres. 